\title{
Hyaluronan Turnover in the Synovial Fluid in Metacarpophalangeal - and Middle Carpal Joints in Standardbred Horses
}

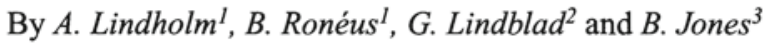 \\ ${ }^{1}$ Department of Medicine and Surgery, ${ }^{3}$ Department of Clinical Chemistry, Faculty of Veterinary Medicine, \\ Swedish University of Agricultural Sciences, Uppsala, and ${ }^{2}$ Pherrovet AB, Box 835, 20180 Malmö, Sweden.
}

\begin{abstract}
Lindholm, A., B. Ronéus, G. Lindblad and B. Jones: Hyaluronan turnover in the synovial fluid in metacarpophalangeal - and middle carpal joints in Standardbred horses. Acta vet. scand. 1996, 37, 147-151. - The biological turnover of hyaluronan (sodium hyaluronate) of different molecular weights $\left(0.6 \times 10^{6}\right.$ and $2.5 \times 10^{6}$ Daltons) was studied in the synovial fluid of the middle carpal and metacarpophalangeal joints of 6 clinically healthy Standardbred horses. The hyaluronan was radioactively labelled with ${ }^{14} \mathrm{C}$. The biological half-life $\left(\mathrm{t}_{1 / 2}\right)$ was calculated from repeated synovial samples after injection of the labelled hyaluronan. The mean $t_{1 / 2}$ in the metacarpophalangeal joints was $9.7 \mathrm{~h}$ for low molecular weight hyaluronan and $8.9 \mathrm{~h}$ for high molecular weight hyaluronan and in the middle carpal joints $16.0 \mathrm{~h}$ and $12.5 \mathrm{~h}$ respectively. There was no significant difference in turnover of the different molecular weights of hyaluronan.
\end{abstract}

sodium hyaluronate; equine joints; arthritis.

\section{Introduction}

Hyaluronan (sodium hyaluronate) is an important component of the synovial fluid and the articular cartilage. It is synthesized by the synoviocytes and the chondrocytes in the joint, but is also synthesized in other tissues in the body (Laurent \& Fraser 1992). In healthy joints the hyaluronan has a high molecular weight, about $3 \times 10^{6}$ Daltons, and has viscoelastic and lubricating properties (Radin et al. 1971, Swann et al. 1974). Extreme or inadequate training and racing may cause trauma to the joints, resulting in inflammatory reactions in the joint capsule and synovial membrane and degenerative processes in the articular cartilage. This degenerative process causes a release of lysosomal enzymes, cytokines, and also a release of prote- oglycan fragments into the synovial fluid (Heinegård et al. 1985, Venn et al. 1993). The activity of inflammatory cells causes a decrease of viscosity of the synovial fluid (Balazs et al. 1967, Greenwald \& Moy 1980). The reduction of viscosity has been associated with depolymerization of the hyaluronan molecule and dilution of the synovial fluid due to the inflammatory effusion (Greenwald \& Moy 1980, Dahl et al. 1985). Intraarticular medication with hyaluronan of different molecular weights is a common treatment in equine joint disease, but the understanding of the mechanisms for the clinical results is still obscure (Rydell et al. 1970, Asheim \& Lindblad 1976, Phillips 1989, Aviad et al. 1988). The turnover rate of hyaluronan in equine joints is therefore of interest. 


\section{Materials and methods}

Six clinically sound standardbred horses, 3 mares and 3 geldings, 6-8 years of age, were selected on the basis of lameness examination and radiological examination with 1 lateral and 1 dorsal view. The horses had no lameness or reaction after flexion tests of the joints. The horses were kept by the clinic for research purposes. Before the study they were exercised daily on a treadmill and kept in a paddock for the rest of the day. During the experiment the horses were kept in stallrest. In each horse the middle carpal and metacarpophalangeal joints of both fore limbs were used in the experiment. To determine the metabolic rate of hyaluronan with different molecular weight, ${ }^{14} \mathrm{C}$ labelled hyaluronan was injected intraarticularly. The labelled hyaluronan was obtained from, and characterized by $\mathrm{Bi}$ Technology General (BTG), Israel. The calculated activity and molecular weight distribution were further evaluated and confirmed by Pharmacia Research Laboratories, Uppsala, Sweden.

Arthrocenteces of the middle carpal joints were performed dorso-laterally with the joint in a flexed position, the metacarpophalangeal joints were injected laterally with the joint slightly flexed. The apparent biological half-life $\left(t_{1 / 2}\right)$ of the hyaluronan in the synovial fluid was determined by measuring the disappearance rate of the ${ }^{14} \mathrm{C}$ labelled hyaluronan. The radioactivity from repeated samplings during $48 \mathrm{~h}$ was measured in an automatic beta-counter with quench correction (1215 Rackarbeta 11, LKB Wallac, Åbo, Finland). The $\mathrm{t}_{1 / 2}$ was calculated by simple regression using the method of least squares.

\section{Experiment 1: Hyaluronan with low molecular weight}

In 4 of the horses, $1 \mathrm{ml}$ containing $1.06 \mathrm{mg}$ sodium hyaluronan with an activity of 829 $\mathrm{kBq} / \mathrm{ml}$ was injected intraarticularly into the middle carpal and metacarpophalangeal joints of both fore legs using aseptic procedures. The mean molecular weight of the hyaluronan was $0.6 \times 10^{6}$ Daltons. Samples $(1 \mathrm{ml})$ of synovial fluid were obtained by arthrocentesis of the injected joint at $30 \mathrm{~min}, 4,8,24$ and $48 \mathrm{~h}$ after injection, and placed in sterile plastic tubes. The samples were kept in a freezer $\left(-20^{\circ} \mathrm{C}\right)$ until analyzed for ${ }^{14} \mathrm{C}$ activity.

\section{Experiment 2: Hyaluronan with high molecular weight}

In 2 of the horses hyaluronan of higher molecular weight, $2.5 \times 10^{6}$ Daltons, was used. One ml containing $5 \mathrm{mg}$ hyaluronan with an activity of $92 \mathrm{kBq} / \mathrm{ml}$ was injected into the middle carpal and metacarpophalangeal joints of both fore limbs.

Synovial fluid samples $(1 \mathrm{ml})$ were collected at the same time intervals as in the previous experiment. In these 2 horses no samples were taken from the carpometacarpal joints.

\section{Results}

No side effects such as lameness, heat, or joint effusion were seen in any of the horses. No or minor bleeding was observed in the synovial fluid samples. No pathological changes were seen on the radiographs.

\section{Experiment 1}

The turnover rate $\left(t_{1 / 2}\right)$ for low molecular weight hyaluronan, $0.6 \times 10^{6}$ Daltons, in the middle carpal joints was as a mean $16.0 \mathrm{~h}$ (range 8.4-22.6) and in the metacarpophalangeal joint $9.7 \mathrm{~h}$ (range 9.0-10.9). There was no difference in turnover rate between samples from the middle carpal and carpometacarpal joints indicating a complete communication between these 2 joint compartments.

\section{Experiment 2}

The $t_{1 / 2}$ of the high molecular weight hyaluro- 
nan, $2.5 \times 10^{6}$ Daltons, did not differ significantly from the low molecular weight hyaluronan. The mean $t_{1 / 2}$ in the middle carpal joints was $12.5 \mathrm{~h}$ (range 8.4-19.8) and in the metacarpophalangeal joints $8.9 \mathrm{~h}$ (range 7.9-9.8).

\section{Discussion}

In this study a small number of horses was used due to the small amount of ${ }^{14} \mathrm{C}$ labelled hyaluronan available for the study. A larger number of subjects was desirable, but still the results give a good appreciation of biological turnover of hyaluronan in the synovial fluid in the joints of horses. The large range in turnover rate, observed in the middle carpal joints, may be a result of individual variations and due to the small number of experimental horses. The turnover rate of hyaluronan in the tissues is surprisingly rapid as hyaluronan has been regarded as a structural component in connective tissue and structural components are usually quite stable (Laurent \& Fraser 1992). The results of the turnover rate in this study are supported by earlier studies in rabbits. The turnover rate in different organs such as joints, skin, eye and intestines in rabbits showed a $t_{1 / 2}$ of about $12 \mathrm{~h}$ in joints and skin, $1 \mathrm{~h}-70$ days in the eye (rapid in the anterior chamber and slow in the vitreous body) and that 9 percent per hour of the tissue hyaluronan in the intestines were washed out at high lymph flow (Laurent et al. 1988, Reed et al. 1990, Brown et al. 1991, Laurent \& Reed 1991).

When measuring turnover rates of substances in the synovial fluid, the concentration of the analyzed substance is measured in the different synovial samples taken by arthrocentesis. The concentration is dependent on the synovial volume, and repeated arthrocenteses may lead to an inflammatory reaction and changes in the synovial fluid volume. However, in earlier studies on hyaluronan and proteoglycans in the syn- ovial fluid in horses, no changes in synovial fluid volume were seen after weekly repeated arthrocentes (Ronéus et al. 1993). This indicates that it appear not to be necessary to determine the synovial fluid volume in every sample taken when performing studies on naturally occuring substances in the synovial fluid. Changes in synovial volume due to inflammatory reactions or minor bleeding secondary to repeated arthrocenteseses are thus possible and may have influenced the results. However, as no clinical signs of increased heat or joint effusion were observed during the study this was considered to be of minor importance.

In this study the $t_{1 / 2}$ has been calculated for hyaluronan of two different molecular weights: $0.6 \times 10^{6}$ and $2.5 \times 10^{6}$ Daltons. Different molecular weights did not seem to influence the rate of biological turnover. However, the turnover rate seems to be different in different joints, as in the present study the $t_{1 / 2}$ was more rapid in the metacarpophalangeal joints than in the middle carpal joints. This may be a result of different workload, range of motion, vascularisation, or the anatomy of the synovial membrane in different joints. It is known that the nutrition of the articular cartilage is dependent on the natural compression of the cartilage during weight bearing and motion of the joint. This stimulates the passive fluid transport to and from the cartilage which is necessary for the nutrition and biological turnover (Muir 1986). Previous studies on synovial fluid have shown a more rapid metabolism in smaller joints than in larger joints (Ekman et al. 1981). Hyaluronan is synthesized by the synovial cells (Laurent \& Fraser 1992). The turnover rate for hyaluronan found in this study was rapid suggesting a high metabolic activity in the synoviocytes. This result is in agreement with earlier studies by Smith \& Gosh (1987) in cell culture systems in which the synthesized hyaluronan did not disappear or was diluted as in the body. 
In the in vivo situation the difference between the synthesized and the eliminated or metabolized hyaluronan is measured. A change in concentration is therefore a consequence of several factors: rate of synthesis, disappearance rate and fluid transport through the synovial membrane leading to changes in the volume of the synovial fluid.

The figures for the turnover rate given in this study are considered valid for the "normal" or healthy joints, assuming that the small amounts of hyaluronan injected do not affect the normal synthesis, elimination rate, or fluid transport significantly. However, the metabolism in an arthritic joint may be completely different, and further studies on the metabolism of hyaluronan in diseased joints are necessary. Hyaluronan produced in the peripheral tissues apart from that which is degraded locally is transported via the lymph, and a major uptake and degradation take part in the lymph nodes. The hyaluronan that leaks out in the blood disappears from the circulation with a half-life of a few min and the major part is taken up by the liver (Laurent \& Fraser 1992).

In the clinical situation hyaluronan is injected intraarticularly in order to treat equine arthritis. This study shows that according to the $t_{1 / 2}$, the injected amount of hyaluronan has disappeared from the joint or has been metabolized in approximately 3 days. In arthritic joints that respond positively after hyaluronan treatment, the hyaluronan must induce a healing process soon after the intraarticular injection. However, the main biological function and the molecular mechanism that regulate the biosynthesis of hyaluronan still remains unknown, but some stimulative factors such as several growth factors and cytokines are known to activate the synthesis (Laurent \& Fraser 1986, Heldin et al. 1989).

\section{References}

Aviad AD, Arthur RM, Brencick VA, Ferguson HC, Teigland MB: Synacid vs. Hylartin V in equine joint disease. J. Equine vet. Sci. 1988, 8, 112-116.

Balazs EA, Watson D, Duff IE, Roseman S: Hyaluronic acid in synovial fluid. I. Molecular parameters of hyaluronic acid in normal and arthritic human fluids. Arthritis Rheum. 1967, 10, 357-376.

Brown TJ, Laurent UBG, Fraser JRE: Turnover of hyaluronan in synovial joints: elimination of labelled hyaluronan from the knee joint of the rabbit. Exp. Physiol. 1991, 76, 125-134.

Dahl LB, Dahl IM, Engström-Laurent A, Granath K: Concentration and molecular weight of sodium hyaluronate in synovial fluid from patients with rheumatoid arthritis and other arthropathies. Ann. Rheum. Dis. 1985, 44, 817-822.

Ekman L, Nilsson G, Persson L, Lumsden LH: Volume of the synovia in certain joint cavities in the horse. Acta vet. scand. 1981, 22, 23-31.

Greenwald RA, Moy $W W$ : Effects of oxygen-derived free radicals on hyaluronic acid. Arthritis Rheum. $1980,23,455-463$.

Heinegård D, Inerot S, Wieslander J, Lindblad G: A method for the quantification of cartilage proteoglycan structures liberated to the synovial fluid during developing degenerative joint disease. Scand. J. Clin. Lab. Invest. 1985, 45, 421-427.

Heldin P, Laurent TC, Heldin C-H: Effect of growth factors on hyaluronan synthesis in cultured human fibroblasts. Biochem. J. 1989, 258, 919-922.

Laurent TC, Fraser JRE: Hyaluronan. The FASEB J., 1992, 6, 2397-2404.

Laurent TC, Fraser JRE: The properties of and turnover of hyaluronan. In: Functions of proteoglycans, Ciba Foundation Symp. Wiey, Chichester, England. 1986, 124, 9-29.

Laurent UBG, Fraser JRE, Laurent TC: An experimental technique to study the turnover of concentrated hyaluronan in the anterior chamber of the rabbit. Exp. Eye Res. 1988, 46, 49-58.

Laurent UBG, Reed RK: Turnover of hyaluronan in the tissues. Adv. Drug Deliv. Rev. 1991, 7, 237 256.

Muir H: Current and future trends in articular cartilage research and osteoarthritis. In: Knetter K E, Schleyerbach R, Hascall V C (eds.).: Articular cartilage Biochemistry. Raven Press, New York, 1986, 423-440.

Phillips $M W$ : Clinical trial comparison of intraarticular sodium hyaluronate products in the horse. J. Equine Vet. Sci. 1989, 9, 39-40. 
Radin EL, Paul IL, Swann DA, Schottstaedt ES: Lubrication of synovial membrane. Ann. Rheum. Dis. 1971, 30, 322.

Reed RK, Laurent UBG, Fraser JRE, Laurent TC: Removal rate of $\left({ }^{3} \mathrm{H}\right)$ hyaluronan injected subcutaneously in rabbits. Amer. J. Physiol. 1990, 259, 532-535.

Roneus B, Lindblad G, Lindholm A, Jones B: Effects of intraarticular corticosteroid and sodium hyaluronate injections on synovial fluid production and synovial fluid content of sodium hyaluronate and proteoglycans in normal equine joints. J.Vet. Med. A. 1993, 40, 10-16.

Rydell NW, Butler J, Balazs EA: Hyaluronic acid in synovial fluid. VI. Effect of intraarticular injection of hyaluronic acid on the clinical symptoms of arthritis in track horses. Acta vet. scand. 1970, 11, 139-155.

Smith MM, Gosh P: The synthesis of hyaluronic acid by human synovial fibroblasts is influenced by the nature of the hyaluronate in the extracellular environment. Rheumatol. Int., 1987, 7, 113-122.

Swann DA, Radin EL, Nazimiek M, Weisser PA, Curran $N$, Lewinnek $G$ : Role of hyaluronic acid in joint lubrication. Ann. Rheum. Dis. 1974, 33, 318.

Venn G, Nietfield JJ, Duits AJ, Brennan FM, Arner E, Covington M, Billingham MEJ, Hardingham TE:
Elevated synovial fluid levels of Interleukin-6 and tumor necrosis factor associated with early experimental canine osteoarthritis. Arthritis Rheum. 1993, 36, 819-826.

Asheim A, Lindblad G: Intraarticular treatment of arthritis in race-horses with sodium hyaluronate. Acta vet. scand. 1976, 17, 379-394.

\section{Sammendrag}

Omsättningshastighet av hyaluronan $i$ synovia från kotleder och mellersta carpus hos varmblodiga travhästar.

Den biologiska omsättningshastigheten för hyaluronan av olika molekylvikt, $0,6 \times 10^{6}$ samt $2,5 \times 10^{6} \mathrm{Dal}-$ tons, studerades i synovian hos 6 friska varmblodiga travhästar.

Radioaktivt märkt $\left({ }^{14} \mathrm{C}\right)$ hyaluronan injicerades intraartikulärt i kotleder och mellersta carpus. Den biologiska halveringstiden, $t 12$, beräknades från synoviaprover erhållna genom opprepade artocenteser.

Den genomsnittliga t $1 / 2 \mathrm{i}$ kotleder var: $9,7 \mathrm{~h}$ för lågmolekylärt och $8,9 \mathrm{~h}$ för högmolekylärt hyaluronan och $\mathrm{i}$ carpus var $\mathrm{t} 1 / 216,0 \mathrm{~h}$ för lågmolekylärt och $12,5 \mathrm{~h}$ för högmolekylärt hyaluronan. Det förelåg ingen signifikant skillnad i omsättningstid mellan hyaluronan av olika molekylvikt.

(Received February 22, 1995; accepted February 9, 1996).

Reprints may be obtained from: A. Lindholm, Department of Medicine \& Surgery, Swedish University of Agricultural Sciences, P.O. Box 7018, S-75007 Uppsala, Sweden. Fax: +46 (0) 18-67 29 19, E-mail: Arne.Lindholm@kirmed.slu.se. 
